https://www.sworldjournal.com/index.php/swj/article/view/swj04-03-018 DOI: 10.30888/2410-6615.2020-04-03-018

УДК 65.012:658.3

EFFICIENCY OF THE COMMUNICATION MANAGEMENT OF THE ENTERPRISE

ЕФЕКТИВНІСТЬ КОМУНІКАЦІЙНОГО МЕНЕДЖМЕНТУ ПІДПРИСМСТВА

Makovetska I. M. / Маковецька I.M. postgraduate student / acnipaнm

Державний університет телекомунікаиій, Київ, вул. Солом'янська 7, 03110 State University of Telecommunications, Kyiv, st. Solomenskaya 7, 03110

\begin{abstract}
Анотація. Наукова стаття присвячена розгляду інформаційно-комунікаційного середовища підприємства. B статті розглянуто ефективність комунікаційного менеджменту підприємства та наведені головні параметри якісної роботи управлінського персоналу завдяки правильно налагодженій комунікації на підприємстві. $B$ статті продемонстровано взаємозв'язок комунікаційного менеджменту з іншими науковими галузями. Встановлено, щзо ефективність комунікаційного менеджменту підприємства залежить від системи управління в інформаційному просторі та від атмосфери взаєморозуміння і співробітництва на иьому ж підприємстві.
\end{abstract}

Ключові слова: ефективність, комунікація, інформація, підприємство, менеджмент

Вступ.

В еру інформаційних технологій та інноваційного буму комунікацію розглядають як інформаційно-комунікаційний засіб спілкування для взаємодії 3 групами людей чи різними підприємствами.

Дослідженнями комунікацій на підприємстві займалися такі іноземні вчені, як Дж.М. Лейхіф [2], Румано Н. С., Нунамакер Дж.Ф. [7], а серед українських цьому питанню приділили багато уваги такі науковці, як М.М. Мандзюк [3], К.С. Суровцева [5], Л.Ю. Сагер [4], О.О. Шубіна [6] та ін.

Наприклад, в працях українського дослідника Шубіна О.O. [6] розглядаються комунікації на підприємстві як одні із стратегічно важливих компонентів управління підприємством, та як такі, що забезпечують інформаційні потоки та якість передавання інформації.

В дослідженні вітчизняного вченого Л.Ю. Сагера [4] аналізується схема організації внутрішнього комунікаційного процесу на підприємстві, та сам автор наводить різні уточнення видів комунікації та перераховує переваги i недоліки різних засобів комунікацій на підприємстві.

Праці закордонних вчених Румано Н. С. та Нунамакера Дж.Ф. [7] присвячені аналізу процесу комунікацій на підприємстві у вигляді різних нарад, зборів та звітностей та показується час який затрачений на цих засіданнях $\mathrm{i}$ яким він $є$ економічно не обгрунтованим і що для цього треба.

Проте дана комунікаційна проблематика потребує подальшого не тільки вивчення, а й удосконалення, так як основні питання ще можуть бути розглянуті в іншій інтерпретації.

\title{
Основний текст
}

Як всім відомо спілкування є одним із спосіб задоволення різноманітних людських потреб: матеріальних, соціальних, культурних, пізнавальних. А змістом спілкування є інформація, яка передається під час спілкування, а 3 
наукової точки зору, то це є обмін думками, ідеями за допомогою різних технічних засобів.

Комунікація в менеджменті - це не тільки обмін інформацією між одержувачем та відправником на отримання інформації при прийнятті ефективних рішень, а й і це є необхідним елементом в управлінській діяльності де потребується розуміння всього комунікаційного процесу за допомогою різних видів і форм менеджменту.

Від формування правильної комунікаційної політики підприємства залежить i робота працівників та самого підприємства. Внутрішньокомунікаційні зв'язки розроблені таким чином, що ділове спілкування під час передачі інформації базується на поведінкових аспектах управлінської діяльності та на взаєморозумінні між співробітниками повідомлень інформаційного характеру.

Інформаційні зв’язки 3 елементами системи менеджменту враховують комунікаційно-організаційні механізми на підприємстві та реалізують вплив на ефективні параметри управління комунікаціями на підприємстві.

Головними параметрами якісної роботи управлінського персоналу завдяки правильно налагодженій комунікації на підприємстві є:

- ефективність наданої інформації;

- швидкість переданої інформації;

- якість отриманої інформації;

- статус оброблення переданої інформації;

- результат комунікації.

Комунікації на підприємстві 3 кожним днем розгортаються все більше i більше. Нові технології, інноваційні рішення, сучасна наукова база - все це покращує та спрощує процес комунікацій на підприємстві. Якщо розглядати комунікації 3 точки зору науки, то краще іiі пізнати як самостійний вид управління в менеджменті, а місце комунікаційного менеджменту в науковій сфері діяльності зображено на рисунку 1.

Взаємозв'язок комунікаційного менеджменту 3 іншими науковими галузями лише покращує управління комунікаціями на підприємстві, бо саме інформаційне забезпечення здійснюється через різні види i форми менеджменту. Саме з точки зору менеджменту, як науки, процес управління комунікаціями варто вважати ефективним, якщо всі суб'єкти передавання інформації продемонстрували розуміння ідеї та швидко зреагували на неї. Комунікаційний менеджмент i $\epsilon$ одним iз головних важелів успіху для підприємства, де - швидкість, гнучкість, уважність і якість є основними атрибутами ефективної комунікації.

Ефективність комунікаційного менеджменту підприємства залежить від:

- сприйняття інформації працівниками підприємства;

- зовнішніх i внутрішніх факторів управління комунікаціями на підприємстві;

- різних комунікаційних бар’єрів, які можуть спричинити неясність в роботі;

- якості зворотного зв'язку. 


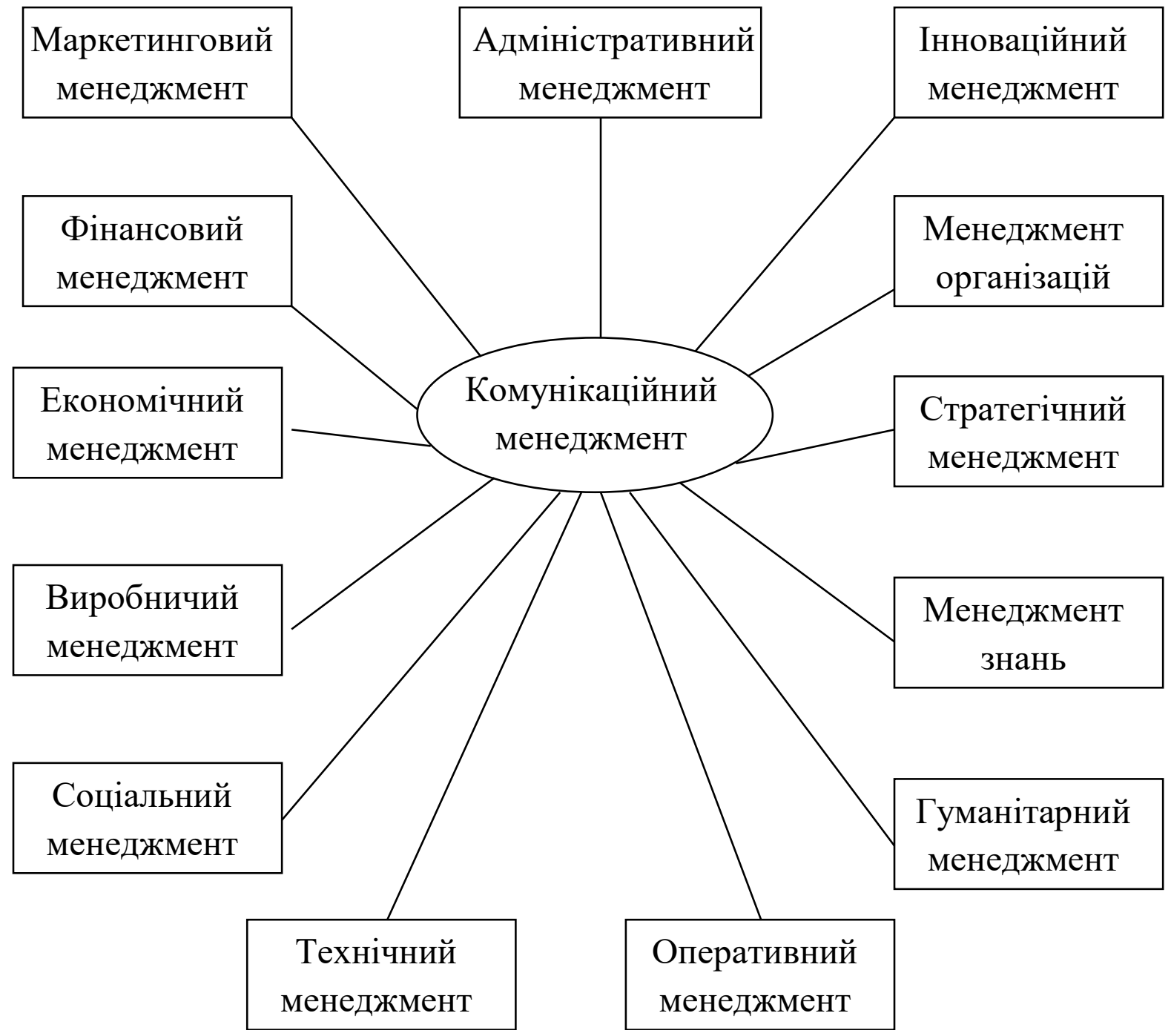

Рис. 1. Взаємозв'язок комунікаційного менеджменту з іншими науковими галузями

Джерело: складено автором на основі [1]

Взаєморозуміння та співпраця на підприємстві добре налаштована в тому випадку, коли всі комунікаційні зв'язки забезпечують адекватне інформування по всім ланкам підприємства. Сам управлінський персонал повинен ефективно працювати над інформаційними потоками на довгострокову перспективу.

\section{Висновки.}

Комунікаційний менеджмент спрямовує свої управлінські сили не лише на досягнення ефективної комунікації між підприємством та його оточуючим середовищем, а й і між відділами самого підприємства.

Була розглянута конструктивна взаємодія між співробітниками підприємства завдяки управлінню комунікацій, яка підкреслює лише наполегливість співробітників i необхідність в їхній роботі різних комунікаційних важелів для успіху діяльності підприємства.

В інформаційно-комунікаційній сфері діяльності комунікаційний менеджмент розглядається не лише як самостійна професійно-наукова діяльність, яка направлена на роботу з усіма суб'єктами господарювання для реалізації комунікаційної стратегії, а й і внутрішньо-організаційне управління 
комунікаціями по корегуванню бізнес-процесів на підприємстві.

Отже, ефективність комунікаційного менеджменту проходить через технологічну складову системи комунікацій на підприємстві, де елементами, які характеризують ефективність процесу комунікацій, $\epsilon$ різні технікоекономічні характеристики та взаєморозуміння співробітниками комунікаційних повідомлень. Інформація має важливе значення для підприємства. Вона пролягає через обмін між його внутрішньо-організаційними складовими та із зовнішнім середовищем підприємства.

Система комунікацій, яка створена на підприємстві складна і трудомістка, а комунікаційні процеси та механізми управління визначають ступінь інформованості управлінського персоналу підприємства.

В ході дослідження було встановлено, що ефективність комунікаційного менеджменту підприємства залежить від системи управління в інформаційному просторі та від атмосфери взаєморозуміння і співробітництва на цьому ж підприємстві. Інформація в комунікаційному менеджменті налагоджується через комунікаційні потоки на підприємства, що виступають базисом в глобальному суспільстві.

Література:

1. Бебик В. М. Інформаційно-комунікаційний менеджмент у глобальному суспільстві: психологія, технології, техніка паблік рилейшнз: монографія, К. : МАУП, 2005. 440 с.

2. Лейхиф Дж.М., Дж.М. Пенроуз. Бизнесс-коммуникации. СПб.: Питер, $2001.688 \mathrm{c}$.

3. Мандзюк М.M. Теоретичні рекомендації щодо вдосконалення управління внутрішньо-організаційними комунікаціями. Управління розвитком. 2011. № 4 (101). С. 180-182

4. Сагер Л.Ю. Удосконалення категорійного апарату комунікацій у системі управління підприємствами. Економічний простір. 2012. № 64. С.243-254.

5. Суровцева Е.С., Рубин Г.Я. Оценка эффективности деятельности по управлению организационными коммуникациями. Организатор производства. 2009. № 4. C. 47-49.

6. Шубін О.О., Сіменко І.В. Аналітична оцінка організаційних комунікацій. Актуальні проблеми економіки. 2010. № 1 (103). С. 175-184.

7. Romano N. C., Nunamaker J. F. Meeting analysis: Findings from research and practice. Proceedings of 34th annual Hawaii International Conference on System Sciences, Maui. HI, 2001 URL: http://www.okstate.edu/ceat/msetm/courses/etm5221/Week201\%20Challenges/Meeti ng\%20Analysis\%20Findings\%20from\%20Research\%20and\%20Practice.pdf

Abstract. The scientific article is devoted to the consideration of the information and communication environment of the enterprise. The article considers the effectiveness of communication management of the enterprise and presents the main parameters of quality work of management staff due to properly established communication at the enterprise. The article demonstrates the relationship of communication management with other scientific fields. It is established that the effectiveness of communication management of the enterprise depends on the 
management system in the information space and the atmosphere of mutual understanding and cooperation at the same enterprise.

Key words: efficiency, communication, information, enterprise, management

Науковий керівник: д.е.н., проф. Гудзь О.Є. Статтю відправлено: 20.05.2020 p. (C) Маковецька I.M. 